\title{
Handicap Transportation Service
}

National Cancer Institute

\section{Source}

National Cancer Institute. Handicap Transportation Service. NCI Thesaurus. Code C159754.

A transportation service directed to, or reserved for, handicapped individuals. 